\title{
Pengaruh Model Pembelajaran Picture and Picture Berbasis Portofolio Terhadap Hasil Belajar IPA Siswa
}

\author{
Ni Putu Rita Purwani¹, I W. Darsana², I. B. S. Manuaba ${ }^{3}$ \\ 1,2,3Jurusan Pendidikan Guru Sekolah Dasar Universitas Pendidikan Ganesha Singaraja, Indonesia
}

\section{ARTICLEIN \\ $\mathrm{FO}$ \\ Article history: \\ Received 18 May \\ 2018 \\ Received in revised \\ form \\ 9 June 2018 \\ Accepted 15 July \\ 2018 \\ Available online 19 \\ August 2018 \\ Kata Kunci: \\ picture and picture, portofolio, hasil \\ belajar IPA.}

Keywords: picture and picture portfolio, science learning outcomes.

\begin{abstract}
A B STRAK
Penelitian ini bertujuan untuk mengetahui pengaruh model pembelajaran picture and picture berbasis portofolio terhadap hasil belajar IPA siswa kelas V SD Gugus II Kecamatan Abiansemal Tahun Ajaran 2017/2018. Jenis penelitian ini adalah eksperimen semu, dengan desain kelompok Non-Ekuivalen. Populasi dari penelitian ini adalah seluruh kelas $\mathrm{V}$ di SD Gugus II Kecamatan Abiansemal yang berjumlah 192 siswa. Sampel diambil dengan teknik random sampling, diperoleh Kelas V SD No 2 Taman sebagai kelompok eksperimen dan Kelas V SD No 1 Selat sebagai kelompok kontrol. Data tentang hasil belajar IPA dikumpulkan dengan instrumen berupa tes objektif. Kemudian data dianalisis dengan menggunakan uji-t, diperoleh thitung $=7,096>$ ttabel=2,000 dengan $\mathrm{dk}=$ $35+34-2=67$ dan taraf signfikansi $5 \%$. Hal ini berarti terdapat perbedaan yang signifikan hasil belajar IPA antara kelompok siswa yang dibelajarkan melalui model pembelajaran picture and picture berbasis portofolio dengan kelompok siswa yang dibelajarkan melalui pembelajaran konvensional pada siswa kelas V SD Gugus II Kecamatan Abiansemal. Hasil penelitian menunjukkan rata-rata gain skor kelas eksperimen $=0,55>=0,33$ kelas kontrol. Dengan demikian dapat disimpulkan bahwa model pembelajaran picture and picture berbasis portofolio berpengaruh terhadap hasil belajar IPA siswa kelas V Gugus II Kecamatan Abiansemal Tahun Ajaran
\end{abstract} 2017/2018. Berdasarkan hasil penelitian ini disarankan agar penelitian ini dapat dijadikan sebagai referensi untuk melaksanakan penelitian selanjutnya bagi peneliti dengan menggunakan model picture and picture berbasis portofoliol.

\section{A B S T R A C T}

The purpose of this research was to find out the significant effect of models picture and picture learning based portfolio toward the science students learning outcomes of $\mathrm{V}$ grade in Elementary School at Abiansemal District academic year 2017/2018. The type of this research was a pseudoexperiment with a non- equivalent group design. The population of this study were all the $\mathrm{V}$ graders in elementary school Gugus II at Abiansemal District, 192 students. Samples were taken by random sampling technique which was obtained that $V$ graders in elementary school No. 2 Taman as the experimental group and $\mathrm{V}$ graders in elementary school No. 1 Selat as the control group. Data on students learning outcomes of science were collected by using the test instrument in the form of objective test. The learning outcomes of science were given as the time of posttest in writing. Then, data were analysed by using t-test, that was obtained tcount $=7,096>$ ttable $=2,000$ with $\mathrm{dk}=35+34$ $-2=67$ and level significance of $5 \%$. This means there is significant difference between the of science students learning outcomes to use the models picture and picture based portfolio with students who learning using conventional on grade $\mathrm{V}$ Elementary School at Abiansemal district academic year 2017/2018. The results showed the average gain score of experimental group $=0,55>=0,33$ control group. So, it could be concluded that the picture and picture learning model based on portfolio had an effect on the science students learning outcomes of V Grade in elementary school Gugus II at Abiansemal district academic year 2017/2018. Based on the results of this research it is recommended that this study can serve as a reference for further research for researchers using the model picture and picture-based portfolio.

Copyright (C) Universitas Pendidikan Ganesha. All rights reserved. 


\section{Pendahuluan}

"Pendidikan adalah segala pengaruh yang diupayakan oleh sekolah terhadap anak yang bersekolah agar mempunyai kemampuan yang sempurna dan kesadaran penuh terhadap hubungan-hubungan dan tugas - tugas sosial"(Kadir, dkk 2012:60).

Husein (2017: 56) menyatakan, tujuan pendidikan memuat gambaran tentang nilai - nilai yang baik, luhur, pantas, benar, dan indah untuk kehidupan. Karena tujuan pendidikan mempunyai dua fungsi yaitu memberi arah kepada segenap kegiatan pendidikan dan merupakan sesuatu yang ingin dicapai oleh segenap kegiatan pendidikan. Tujuan pendidikan menduduki posisi penting diantara komponen komponen pendidikan lainnya.Oleh karena itu, peningkatan kualitas pendidikan merupakan suatu usaha yang secara terus-menerus dilaksanakan dengan sebaik-baiknya, agar tercapainya tujuan dari pendidikan secara maksimal dan pendidikan tidak bisa lepas dengan kegiatan proses pembelajaran.

"Pembelajaran merupakan suatu proses interaksi antara guru dengan siswa, baik interkasi secara langsung seperti kegiatan tatap muka secara langsung maupun secara tidak langsung, yaitu dengan menggunakan berbagai media pembelajaran" (Rusman,2016:134). Pembelajaran harus menumbuhkan suasana sedemikian rupa sehingga siswa aktif bertanya, mempertanyakan, dan mengemukakan gagasan (Wisesa, 2014)

Jadi pembelajaran merupakan proses untuk membantu siswa belajar dengan baik dalam melakukan interaksi secara langsung atau tidak. Komponen utama dalam sebuah pembelajaran ialah siswa yang berkedudukan sebagai subjek belajar yang harus ada disetiap sekolah dan guru sebagai fasilitator pembelajaran. Guru sebagai fasilitator pembelajaran berpengaruh dalam kegiatan proses pembelajaran agar terciptanya suasana belajar yang menyenangkan. Suasana yang menyenangkan dapat menumbuhkan kegairahan belajar, sedangkan suasana yang kacau, ramai, tak tenang, dan banyak gangguan, sudah tentu tidak menunjang kegiatan yang belajar efektif, sehingga dapat mempengaruhi pencapaian hasil belajar siswa.

Hasil belajar dapat dilihat melalui tingkat keberhasilan siswa dalam memahami materi pelajaran yang disampaikan, diharapkan dalam proses kegiatan pembelajaran siswa memperoleh hasil belajar yang maksimal disetiap mata pelajaran begitu pula dengan mata pelajaran IPA (Ilmu Pengetahuan Alam). "IPA merupakan rumpun ilmu, memiliki karakteristik khusus yaitu mempelajari fenomena alam yang faktual, baik berupa kenyataan atau kejadian dan hubungan sebab-akibatnya" (Wisudawati dan Sulistyowati, 2015:22). Pendidikan IPA merupakan salah satu kompetensi yang harus dimiliki siswa, karena pendidikan IPA memiliki peranan yang penting dalam meningkatkan mutu pendidikan (Jaya, 2014). IPA berhubungan dengan cara mencari tahu tentang alam secara sistematis, sehingga IPA bukan hanya penguasaan kumpulan pengetahuan yang berupa fakta-fakta, konsep-konsep, atau prinsip-prinsip saja tetapi juga merupakan suatu proses penemuan (Kurniati, 2014).

Berdasarkan hasil observasi yang dilakukan pada tanggal 10 Januari 2018 pada kelas V di SD Gugus II Kecamatan Abiansemal, dilihat dari nilai ulangan umum semester I, sebagian hasil belajar IPA siswa masih ada dibawah Kriteria Ketuntasan Minimal ( KKM). Dari 192 siswa terdapat 146 atau 76,04\% siswa yang mendapatkan nilai diatas KKM, sedangkan siswa yang masih dibawah KKM sebanyak 46 atau 23,95\%. Berkaitan dengan hal ini ada beberapa faktor yang mempengaruhi hal tersebut seperti siswa kurang aktif dalam kegiatan pembelajaran dan dalam penggunaan model pembelajaran belum berjalan secara optimal karena lebih banyak menggunakan metode ceramah, sehingga pembelajaran menjadi kurang menarik. Ini menyebabkan masih ada hasil belajar IPA siswa yang dibawah KKM, maka dari itu telah dilakukan berbagai upaya dalam peningkatan mutu pembelajaran IPA disekolah untuk menyikapi hal tersebut, maka model-model pembelajaran dapat diterapkan oleh guru. Salah satunya model pembelajaran picture and picture.

Dari informasi yang diperoleh di Gugus II Kecamatan Abiansemal, belum pernah menerapkan model pembelajaran yang inovatif seperti model pembelajaran picture and picture dengan berbasis portofolio. Dengan dikembangkannya model pembelajaran picture and picture berbasis portofolio ini dapat membantu siswa memahami materi pembelajaran melalui kegiatan mengurutkan gambar sehingga apa yang diperoleh saat proses pembelajaran berlangsung dapat lebih melekat pada ingatan siswa. Huda (2013:236) menyatakan, picture and picture merupakan strategi pembelajaran yang menggunakan gambar sebagai media pembelajaran. Keberhasilan siswa dalam menerima materi pembelajaran dapat diketahui melalui portofolio. . Model pembelajaran picture and picture sangat cocok diterapkan untuk muatan materi IPA (Handayani, 2017).

Sanjaya,(2009:362) menyatakan, portofolio sebagai kumpulan karya siswa yang disusun secara sistematis dan teroganisir sebagai hasil usaha pembelajaran yang telah dilakukannya dalam kurun waktu tertentu. Maka dari itu portofolio dipadukan dengan model pembelajaran picture and picture. 
Model pembelajaran picture and picture berbasis portofolio merupakan model pembelajaran yang mengandalkan gambar pada saat proses pembelajaran berlangsung dengan mengurutkan gambar secara logis. Dalam proses kegiatan pembelajaran siswa juga mengerjakan tugas-tugas yang berkaitan dengan topik yang dibahas baik itu berupa laporan hasil pengamatan, lembar kerja siswa dan yang lainnya, kemudian dikumpulkan dalama satu dokumen untuk mengetahui perkembangan kemampuan siswa. Dengan adanya portofolio dalam proses kegiatan pembelajaran akan dapat membantu guru untuk lebih mudah mengetahui perkembangan siswa secara individu dan dapat memberikan perbaikan terhadap hasil belajar IPA siswa yang belum optimal.

Purwanto(2011:49) menyatakan, hasil belajar adalah perwujudan kemampuan akibat perubahan perilaku yang dilakukan oleh usaha pendidikan, kemampuan menyangkut domain kognitif, afektif dan psikomotorik. Hasil belajar IPA merupakan perubahan kemampuan siswa yang didapat melalui proses pendidikan yang menyangkut aspek kognitif, afektif dan psikomotor setelah melalui proses latihan dalam kegiatan pembelajaran IPA.

Berdasarkan paparan diatas, maka akan dilaksanakan penelitian dengan judul " Pengaruh Model Pembelajaran Picture and Picture Berbasis Portofolio Terhadap Hasil Belajar IPA Siswa Kelas V SD Gugus II Kecamatan Abiansemal Tahun Ajaran 2017/2018".

\section{Metode}

Penelitian ini menggunakan jenis penelitian kuantitatif, pemilihan SD Gugus II Kecamatan Abiansemal sebagai tempat penelitian karena keterjangkauan dan kelayakan. Kerterjangkauan dalam arti tempat penelitian mudah untuk dijangkau oleh peneliti, dan kelayakan dalam artian di SD Gugus II Kecamatan Abiansemal belum pernah dilakukan penelitian yang sama dengan penelitian ini. Penelitian ini dilaksanakan dengan menggunakan rancangan penelitian eksperimen semu (quasi exsperiment). Sugiyono, (2012:114) Desain ini memiliki kelompok kontrol, tetap tidak dapat berfungsi sepenuhnya untuk mengontrol variabel-variabel luar yang mempengaruhi pelaksanaan eksperimen. Desain eksperimen semu yang akan digunakan pada penelitian ini adalah Nonequivalent Control Group Design, rancangan penelitian ini dipilih karena eksperimen dilakukan pada kelas dengan siswa yang ada adalah setara. Rancangan penelitian yang akan digunakan pada penelitian ini digambarkan sebagai berikut:

\begin{tabular}{|ccc|}
\hline O1 & X & O2 \\
\hline O3 & & O4 \\
\hline
\end{tabular}

(Sumber :Sugiyono, 2012: 116)

Gambar 1. Rancangan kelompok Non-equivalent

Setyosari (2015: 221) menyatakan, populasi merupakan keseluruhan dari objek, orang, peristiwa, atau sejenisnya yang menjadi perhatian dan kajian dalam penelitian. Populasi dalam penelitian ini adalah siswa kelas V SD Negeri yang terdapat pada Gugus II Kecamatan Abiansemal Tahun Ajaran 2017/2018 terdapat 8 SD yaitu SD No 1 Selat, SD No 1 Punggul, SD No 2 Punggul, SD No 1 Taman, SD No 2 Taman, SD No 3 Taman, SD No 4 Taman, SD No 5 Taman yang berjumlah 192 siswa. Pengambilan sampel pada penelitian ini menggunakan teknik random sampling yang diacak adalah kelasnya, sehingga setiap kelas mendapatkan peluang yang sama untuk menjadi sampel penelitian. Agung (2014: 71) menyatakan, “ sampling random merupakan cara pengambilan sampel dengan memberikan kesempatan yang sama kepada anggota populasi untuk diambil menjadi anggota sampel". Hasil pengundian diperoleh SD No 1 Selat dengan jumlah siswa 34 siswa dan SD No 2 Taman dengan jumlah siswa 35 siswa. Selanjutnya, dilakukan penyetaraan terhadap kedua kelas untuk memastikan tidak ada perbedaan rata-rata nilai kemampuan belajar IPA siswa, maka diberikan pretest untuk menentukan kesetaraan. Nilai atau skor dari hasil pretest yang dilakukan tersebut digunakan untuk penyetaraan kedua kelas yang menjadi sampel dengan menggunakan uji kesetaraan (uji t), yaitu dengan menggunakan rumus polled varians.

Dengan kriteria pengujian, pada taraf signifikansi $5 \%$ dengan $\mathrm{dk}=n_{1}+n_{2}-2$, bila $t_{\text {hitung }} \leq \mathrm{t}_{\text {tabel }}$, maka $\mathrm{H}_{0}$ diterima dan $\mathrm{H}_{a}$ ditolak sehingga kelas setara. Bila $t_{\text {hitung }}>t_{\text {tabel, }}$, maka $\mathrm{H}_{0}$ ditolak dan $\mathrm{H}_{a}$ diterima sehingga kelas tidak setara.

Sebelum dilakukan uji kesetaraan, terlebih dahulu dilakukan uji prasyarat analisis yang meliputi uji normalitas sebaran data dan uji homogenitas varians. Uji normalitas kedua sampel dilakukan menggunakan analisis Kolmogorrov-Smirnov. Adapun rekapitulasi hasil uji normalitas data pretest hasil 
belajar IPA pada siswa kelas V SD Gugus II Kecamatan Abiansemal. Hasil dari perhitungan uji kesetaraan kelas sampel yang digunakan disajikan pada tabel berikut.

Tabel 1 : Hasil Uji Normalitas Sebaran Data Kelas Eksperimen dan Kelas Kontrol

\begin{tabular}{|c|c|c|c|c|}
\hline No & Sampel & $\begin{array}{l}\text { Nilai } \quad\left|F_{T}-F_{S}\right| \\
\text { terbesar }\end{array}$ & $\begin{array}{l}\text { Nilai Tabel Kolmogorov- } \\
\text { Smirnov }\end{array}$ & Kesimpulan \\
\hline 1. & $\begin{array}{l}\text { SD No } 2 \text { Taman } \\
\text { Kelas Eksperimen }\end{array}$ & 0,102 & 0,224 & Normal \\
\hline 2. & $\begin{array}{l}\text { SD No } 1 \text { Selat } \\
\text { Kelas Kontrol }\end{array}$ & 0,133 & 0,227 & Normal \\
\hline
\end{tabular}

Berdasarkan perhitungan hasil uji normalitas sebaran data pretest SD No 2 Taman nilai kelas eksperimen diperoleh =0,102. Pada taraf signifikansi 5\% dengan $\mathrm{n}=35$ diperoleh nilai tabel KolmogorovSmirnnov $=0,224$ karena nilai maksimum $\left|F_{T}-F_{S}\right|$ terbesar $=0,102<$ nilai tabel KolmogorovSmirnov $=0,224$ maka data berdistribusi normal. Dan perhitungan hasil uji normalitas sebaran data pretest SD No 1 Selat, nilai pretest kelas kontrol diperoleh $=0,133$. Pada taraf signifikansi $5 \%$ dengan $\mathrm{n}$ $=34$ diperoleh nilai tabel Kolmogorov-Smirnnov $=0,227$ karena nilai $\mathrm{m}\left|F_{T}-F_{S}\right|$ terbesar $=0,133<$ nilai tabel Kolmogorov-Smirnov $=0,227$ maka data berdistribusi normal.

Tabel 2 : Hasil Uji Homogenitas Kelas Eksperimen dan Kelas Kontrol

\begin{tabular}{cccccccc}
\hline No & Sampel & $s_{1}^{2}$ & $s_{2}^{2}$ & $\mathrm{dk}$ & $\mathrm{F}_{\text {hitung }}$ & $\mathrm{F}_{\text {tabel }}$ & Kesimpulan \\
\hline 1 & Uji Homogenitas & 161,47 & 148,22 & $\begin{array}{c}(34) \\
(33)\end{array}$ & 1,09 & 1,82 & Homogen \\
\hline
\end{tabular}

Berdasarkan perhitungan tersebut diperoleh $\mathrm{F}_{\text {hitung }}=1,09$. Harga tersbut kemudian dibandingkan dengan harga $F_{\text {tabel }}$ pada taraf signifikansi 5\% dengan dk pembilang 35-1 = 34 dan dk penyebut 34-1 = 33 diperoleh $F_{\text {tab } \theta l}=1,82$. Ini berarti $F_{\text {hitung }}=1,09<F_{\text {tabel }}=1,82$ sehingga data homogen. Karena data nilai pretest kelas eksperimen dan kelas kontrol berdistribusi normal dan homogen dilanjutkan dengan melakukan uji kesetaraan dengan uji-t. Adapun hasil analisis uji kesetaraan pretest hasil belajar IPA yaitu sebagai berikut.

Tabel 3 : Hasil Analisis Kesetaraan Sampel

\begin{tabular}{lllllllll}
\hline No & Sampel & $\mathrm{n}$ & $\mathrm{dk}$ & $\bar{X}$ & $\mathrm{~s}^{2}$ & $\mathrm{t}_{\text {hitung }}$ & $\mathrm{t}_{\text {tabel }}$ & Keterangan \\
\hline 1 & $\begin{array}{l}\text { SD No 2 } \\
\text { Taman Kelas } \\
\text { eksperimen }\end{array}$ & & 67 & 58,76 & 161,47 & & & \\
& $\begin{array}{l}\text { SD No 1 Selat } \\
\text { Kelas kontrol }\end{array}$ & & & 58,63 & 148,22 & 0,043 & 2,000 & Setara \\
\hline
\end{tabular}

Berdasarkan hasil analisis, diperoleh $t_{\text {hitung }}=0,043$. Harga tersebut kemudian dibandingkan dengan harga $t_{\text {tabel }}$ dengan $d \mathrm{k}=(35+34-2)=67$ dan pada taraf signifikansi $5 \%$ sehingga diperoleh $t_{\text {tabel }}$ $=2,000$ karena $t_{\text {hitung }}=0,043<t_{\text {tabel }}=2,000$ sehingga kedua kelas tersebut dinyatakan setara. Selanjutnya pengundian tahap kedua untuk menentukan kelas eksperimen dan kelas kontrol. Kelas pertama yang muncul ketika pertama diundi dijadikan kelas eksperimen, sedangkan kelas kedua dijadikan kelas kontrol. Berdasarkan hasil undian, diperoleh SD No 2 Taman sebagai kelas ekperimen dengan jumlah siswa 35 siswa dan SD No 1 Selat sebagai kelas kontrol dengan jumlah 34 siswa.

Analisis data dalam penelitian kuantitatif merupakan kegiatan setelah data dari seluruh responden atau sumber data terkumpul. Data hasil pretest dan posttest yang terkumpul dari kelas eksperimen dan kelas kontrol dianalisis terlebih dahulu dengan mencari gain skor yang dinormalisasi. Dalam menganalisis data digunakan teknik analisis statistik deskriptif dan statistik inferensial. Agung, (2014:110) menyatakan analisis statistik deskriptif adalah suatu cara pengolahan data yang dilakukan dengan jalan menerapkan 
rumus-rumus statistik deskriptif. Statistik deskriptif yang digunakan untuk menggambarkan hasil penelitian dalam penelitian ini. Agung, (2014:110) menyatakan, analisis statistik inferensial ialah suatu cara pengolahan data yang dilakukan dengan jalan menerapkan rumus-rumus statistik inferensial untuk menguji suatu hipotesis penelitian yang diajukan peneliti dan kesimpulan ditarik berdasarkan hasil pengujian terhadap hipotesis. Statistik Inferensial bertujuan untuk menguji hipotesis penelitian. Sebelum menguji hipotesis penelitian dilakukan beberapa uji prasyarat analisis data yaitu uji normalitas dan uji homogenitas. Pengujian hipotesis terhadap hipotesis no (H0) menggunakan uji t dengan rumus polled varians.

\section{Hasil dan Pembahasan}

Berdasarkan Uji normalitas sebaran data dilakukan pada kedua kelas, data yang meliputi data kelas yang dibelajarkan melalui model pembelajaran picture and picture berbasis portofolio dan data kelas yang dibelajarkan melalui pembelajaran konvensional. Ini dilakukan untuk mengetahui sebaran data gain skor hasil belajar IPA yang akan digunakan dalam pengujian hipotesis. Dengan kriteria pengujian pada taraf signifikansi $5 \%$ apabila nilaimaksimum $\left|F_{T}-F_{S}\right|<$ nilai tabel Kolmogorov-Smirnov, maka data berdistribusi normal. Sebaliknya jika maksimum $\left|F_{T}-F_{S}\right|>$ nilai tabel Kolmogorov-Smirnov, maka data tidak berdistribusi normal.

Tabel 4 . Hasil Uji Normalitas Sebaran Data Gain Skor Hasil Belajar IPA

\begin{tabular}{lllll}
\hline NO & Sampel & $\begin{array}{l}\text { Nilai } \\
\left|F_{T}-F_{S}\right|_{\text {terbesar }}\end{array}$ & $\begin{array}{l}\text { Nilai } \\
\text { Kolmogorov- mirnov }\end{array}$ & $\begin{array}{r}\text { Tabel } \\
\end{array}$ \\
\hline 1 & $\begin{array}{l}\text { SD No 2 Taman (Kelas } \\
\text { Eksperimen ) }\end{array}$ & 0,173 & 0,224 & Normal \\
2 & $\begin{array}{l}\text { SD No 1 Selat } \\
\text { (Kelas Kontrol) }\end{array}$ & 0,165 & 0,227 & Normal \\
\hline
\end{tabular}

Berdasarkan perhitungan hasil uji normalitas sebaran data gain skor di kelas V SD No 2 Taman kelas eksperimen diperoleh $=0,173$ dan pada taraf signifikansi $5 \%$ dengan $n=35$, diperoleh nilai tabel Kolmogorov-Smirnnov $=0,224$ karena nilai $\left|\mathrm{F}_{\mathrm{T}}-\mathrm{F}_{\mathrm{s}}\right|$ tersebar diperoleh $=0,173<$ nilai tabel kolmogorovSmirnov $=0,224$ maka data berdistribusi normal. Perhitungan hasil uji normalitas sebaran data gain skor SD No 1 Selat kelas kontrol diperoleh $=0,165$ dan pada taraf signifikansi $5 \%$ dengan $n=34$ diperoleh nilai tabel Kolmogorov-Smirnnov $=0,227$ karena nilai $\left|F_{T}-F_{S}\right|$ terbesar $=0,165<$ nilai tabel Kolmogorov-Smirnov $=0,227$ maka data berdistribusi normal.

Setelah melaksanakan uji normalitas sebaran data, lalu dilanjutkan dengan melaksanakan uji homogenitas varian. Uji homogenitas varians dilakukan berdasarkan data hasil belajar IPA yang menggunakan data gain skor kelas eksperimen yang dibelajarkan dengan model pembelajaran picture and picture berbasis portofolio dan kelas kontrol yang dibelajarkan dengan pembelajaran konvensional. Kelas eksperimen dalam penelitian ini adalah kelas V SD No 2 Taman yang bejumlah 35 siswa dan kelas kontrol dalam penelitian ini adalah kelas V SD No 1 Selat yang bejumlah 34 orang siswa. Untuk menentukan homogenitas varians menggunakan uji F. Kriteria pengujian, jika $F_{h i t} \leq F_{\text {tabel }}$ maka sampel homogen. Jika $F_{\text {hitung }}>F_{\text {tabel }}$ maka varian tidak homogen. Pengujian dilakukan pada taraf signifikansi 5\% dengan derajat kebebasan untuk pembilang $\mathrm{n}_{1}-1$ dan derajat kebebasan untuk penyebut $\mathrm{n}_{2}$-1.Pengujian homogenitas varians dijabarkan sebagai berikut.

Tabel 5 : Hasil Uji Homogenitas Varian Data Gain Skor Hasil Belajar IPA

\begin{tabular}{llllllll}
\hline No & Sampel & $s_{1}^{2}$ & $s_{2}^{2}$ & $\mathrm{dk}$ & $\mathrm{F}_{\text {hitung }}$ & $\mathrm{F}_{\text {tabel }}$ & Kesimpulan \\
\hline 1 & Uji Homogenitas & 0,04 & 0,03 & $(34)(33)$ & 1,33 & 1,82 & Homogen \\
\hline
\end{tabular}

Berdasarkan perhitungan tersebut, diperoleh $\mathrm{F}_{\text {hitung }}=1,33$. Harga tersebut kemudian dibandingkan dengan harga $F_{\text {tabel }}$ pada taraf signifikansi 5\% dengan dk pembilang 35-1 = 34 dan dk penyebut 34-1= 33 diperoleh $\mathrm{F}_{\text {tabel }}=1$,82. Ini berarti $\mathrm{F}_{\text {hitung }}=1,34<\mathrm{F}_{\text {tabel }}=1,82$ sehingga data hasil belajar IPA kelas eksperimen dan kelas kontrol mempunyai varians yang homogen. Hipotesis penelitian ini yang diuji 
adalah $\mathrm{H}_{\mathrm{o}}$, yaitu tidak terdapat perbedaan yang signifikan hasil belajar IPA antara kelompok siswa yang dibelajarkan melalui model pembelajaran picture and picture berbasis portofolio dengan kelompok siswa yang dibelajarkan melalui pembelajaran konvensional pada siswa kelas V SD Gugus II Kecamatan Abiansemal Tahun Ajaran 2017/2018. Berdasarkan hasil uji normalitas sebaran data dan uji homogenitas varians diperoleh data kedua kelompok berdistribusi normal dan varians kedua kelas homogen, maka uji statistik yang digunakan dalam penelitian ini adalah uji-t dengan rumus polled varians. Dengan kriteria pengujian adalah Ho ditolak jika $t_{\text {hitung }}>t_{\text {tabel. }} T_{\text {tabel }}$ dengan $d k=n 1+n 2-2, d k=35+34-2=67$ pada taraf signifikansi $5 \%$.

Berdasarkan nilai rata-rata gain skor pada kelas eksperimen yaitu diperoleh $\bar{X}=0,55$ dan kelas kontrol yaitu $\bar{X}=0,33$ dengan varians $s_{1}^{2}=0,04$ dan $s_{2}^{2}=0,03$. Pada penelitian ini masing-masing siswa pada kelas ekperimen berjumlah 35 siswa dan kelas kontrol berjumlah 34 siswa. Dari hasil uji prasyarat yaitu uji normalitas sebaran data dan homogenitas diperoleh bahwa data dari kelas eksperimen dan kelas kontrol berdistribusi normal dan homogen.

Tabel 6 : Hasil Uji Hipotesis

\begin{tabular}{lllllllll}
\hline No & Sampel & $\mathrm{n}$ & $\mathrm{dk}$ & $\bar{X}$ & $\mathrm{~s}^{2}$ & $\mathrm{t}_{\text {hitung }}$ & $\mathrm{t}_{\text {tabel }}$ & Keterangan \\
\hline 1 & $\begin{array}{l}\text { SD No 2 } \\
\text { Taman Kelas } \\
\text { eksperimen }\end{array}$ & 67 & 0,55 & 0,04 & & & \\
2 & $\begin{array}{l}\text { SD No 1 Selat } \\
\text { Kelas kontrol }\end{array}$ & & 0,33 & 0,03 & 7,096 & 2,000 & Ho ditolak \\
\hline
\end{tabular}

Hasil analisis uji-t diperoleh adalah $t_{\text {hitung }}=7,096$. Harga tersebut kemudian dibandingkan dengan harga $t_{\text {tabel }}$ dengan $\mathrm{dk}=35+34-2=67$ dan taraf signifikansi $5 \%$ sehingga diperoleh $t_{\text {tabel }}=2,000$ karena $t_{\text {hitung }}=7,096>t_{\text {tabel }}=2,000$ terdapat perbedaan yang signifikan hasil belajar IPA antara kelompok siswa yang dibelajarkan melalui model pembelajaran picture and picture berbasis portofolio dengan kelompok siswa yang dibelajarkan melalui pembelajaran konvensional pada siswa kelas V SD Gugus II Kecamatan Abiansemal Tahun Ajaran 2017/2018.

Berdasarkan hasil analisis menggunakan uji-t diperoleh $t_{\text {hitung }}=7,096$. Sedangkan dengan $\mathrm{dk}=$ $35+34-2=67$ dan taraf signifikansi $5 \%$ diperoleh nilai $t_{\text {tabel }}=2,000$ sehingga $t_{\text {hitung }}=7,096>t_{\text {tabel }}=2,000$ maka $\mathrm{H}_{\mathrm{o}}$ ditolak. Hal ini berarti terdapat perbedaan yang signifikan hasil belajar IPA antara kelompok siswa yang dibelajarkan melalui model pembelajaran picture and picture berbasis portofolio dengan kelompok siswa yang dibelajarkan melalui pembelajaran konvensional pada siswa kelas V SD Gugus II Kecamatan Abiansemal Tahun Ajaran 2017/2018.

Perolehan hasil perhitungan analisis data menunjukkan bahwa rata-rata gain skor hasil belajar IPA siswa yang menggunakan model picture and picture berbasis portofolio yaitu 0,55. Dari rata-rata tersebut, kemudian dikategorikan pada PAN skala lima sehingga dapat diketahui hasil belajar IPA siswa kelas eksperimen berada pada kategori cukup baik sedangkan rata-rata gain skor hasil belajar IPA siswa yang mengikuti pembelajaran konvensional yaitu 0,33. Dari rata-rata tersebut, kemudian dikategorikan pada PAN skala lima sehingga dapat diketahui hasil belajar IPA siswa kelas eksperimen berada pada kategori cukup baik. Walaupun sama-sama berada pada kategori cukup baik, hasil rentangan yang diperoleh pada setiap kelompok berbeda sehingga hanya berlaku pada kelompok yang bersangkutan dan tidak dapat dibandingkan dengan kelompok lain. Namun dilihat dari rata-rata gain skor tersebut kelas eksperimen mempunyai rata-rata lebih tinggi dibandingkan dengan rata-rata kelas kontrol. Hal ini berarti kelompok yang diberikan perlakuan dengan menggunakan model pembelajaran picture and picture berbasis portofolio berpengaruh terhadap hasil belajar IPA siswa kelas V SD Gugus II Kecamatan Abiansemal.

Hal tersebut disebabkan karena model pembelajaran picture and picture berbasis portofolio dapat membuat siswa menjadi lebih giat dalam belajar, membuat siswa aktif, kreatif, inovatif, dan mampu berinteraksi dalam pembelajaran, karena kegiatan pembelajaran menggunakan model picture and picture berbasis portofolio dapat menciptakan kegiatan belajar yang memberikan kegembiraan bagi siswa melalui kegiatan mengurutkan gambar secara logis tersebut.

Dalam kegiatan proses pembelajaran dengan menerapkan model pembelajaran picture and picture berbasis portofolio, siswa juga mengerjakan tugas -tugas yang berkaitan dengan topik yang dibahas baik itu berupa laporan hasil pengamatan, lembar kerja siswa dan yang lainnya, kemudian dikumpulkan dalam satu dokumen untuk mengetahui perkembangan kemampuan siswa dalam memahami materi yang disampaikan oleh guru. Hal tersebut dapat membuat kegiatan proses pembelajaran IPA menjadi lebih 
cepat dipahami oleh siswa serta siswa dapat mengetahui kemampuannya sendiri melalui portofolio yang dimilikinya. Sehingga berdampak positif terhadap hasil belajar IPA. Adapun kelebihan dari model pembelajaran picture and picture menurut Shoimin (2014:125) sebagai berikut. (1) Memudahkan siswa untuk memahami apa yang dimaksudkan oleh guru ketika menyampaikan materi pembelajaran. (2) Siswa cepat tanggap atas materi yang disampaikan karena diiringi dengan gambar - gambar. (3) Siswa dapat membaca satu per satu sesuai dengan petunjuk yang ada pada gambar-gambar yang diberikan. (4) Siswa lebih berkonsentrasi dan merasa asyik karena tugas yang diberikan oleh guru berkaitan dengan permainan mereka sehari-hari, yakni bermain gambar. (5) Adanya saling kompetesi antar kelompok dalam penyusunan gambar yang telah dipersiapkan oleh guru sehingga suasana kelas terasa hidup. (6) Siswa lebih kuat mengingat konsep-konsep atau bacaan yang ada pada gambar. (7) Menarik bagi siswa dikarenakan melalui audio visual dalam bentuk gambar-gambar.

Hal ini menyebabkan siswa dapat menerima pembelajaran dengan baik, berbeda dengan pembelajaran konvensional yang terjadi selama pembelajaran IPA di kelas kontrol. Kegiatan pembelajaran dilakukan dengan cara menyampaikan materi kepada siswa lebih banyak mendengarkan penjelasan guru kemudian diikuti dengan pemberian tugas. Dengan pembelajaran ini siswa tidak dapat mengembangkan kemampuan. Hasil penelitian ini sejalan dengan penelitian yang dilakukan oleh Fatimah (2016) yang menunjukkan bahwa penggunaan model pembelajaran picture and picture berpengaruh terhadap hasil belajar pada subtema indonesiaku bangsa yang berbudaya kelas V SD Negeri 30 Banda Aceh. Penelitian Susanti (2017) menunjukkan bahwa penerapan model picture and picture berbasis pedekatan saintifik dapat meningkatkan penguasaan kompetensi pengetahuan IPA siswa kelas IV SD N 6 Sumerta Tahun ajaran 2016/2017.

\section{Simpulan dan Saran}

Berdasarkan analisis data hasil belajar IPA pada kelas eksperimen yang dibelajarkan dengan model Pembelajaran picture and picture berbasis portofolio diperoleh rata-rata gain skor, $=0,55$. Ratarata gain skor hasil belajar IPA tersebut kemudian dikonversikan pada PAN skala lima, sehingga dapat diketahui hasil belajar IPA siswa kelas eksperimen berada pada kategori Cukup Baik.

Berdasarkan analisis data hasil belajar IPA pada kelas kontrol yang dibelajarkan melalui pembelajaran konvensional diperoleh skor rata-rata gain skor, $=0,33$. Rata-rata gain skor hasil belajar IPA tersebut kemudian dikonversikan pada tabel PAN skala lima, sehingga dapat diketahui hasil belajar IPA siswa kelas kontrol pada kategori Cukup Baik.

Berdasarkan hasil analisis dengan menggunakan uji t diperoleh thitung $=7,096$. Harga tersebut kemudian dibandingkan dengan harga ttabel dengan $\mathrm{dk}=67 \mathrm{dan}$ taraf signifikansi 5\% sehingga diperoleh ttabel $=2,000$ karena thitung $=7,096>$ ttabel $=2,000$ maka Ho ditolak. Ini berarti terdapat perbedaan yang signifikan hasil belajar IPA antara kelompok siswa yang dibelajarkan melalui model pembelajaran picture and picture berbasis portofolio dengan kelompok siswa yang dibelajarkan melalui pembelajaran konvensional pada siswa kelas V SD Gugus II Kecamatan Abiansemal Tahun Ajaran 2017/2018. Dengan rata-rata gain skor hasil belajar IPA siswa kelas eksperimen $=0,55>=0,33$ rata-rata hasil belajar IPA kelas kontrol, sehingga dapat disimpulkan bahwa model pembelajaran picture and picture berbasis portofolio berpengaruh terhadap hasil belajar IPA siswa kelas V SD Gugus II Kecamatan Abiansemal Tahun Ajaran 2017/2018.

Berdasarkan hasil penelitian, maka saran yang dapat diajukan sebagai berikut. 1) Kepada Guru. Berdasarkan temuan penelitian yang diperoleh, disarankan kepada guru agar lebih kreatif dan inovatif untuk memberikan fasilitas berupa sumber belajar dan kesempatan yang lebih besar bagi siswa pada pembelajaran dengan menggunakan model Picture and Picture berbasis portofolio sehingga tercipta pembelajaran bermakna untuk siswa. 2) Kepada Kepala Sekolah. Berdasarkan temuan penelitian, disarankan kepada kepala sekolah agar dapat menggunakan hasil penelitian ini sebagai pendukung sumber belajar guru dalam meningkatkan kualitas pembelajaran dengan menciptakan pembelajaran yang menggembirakan di sekolah sehingga sekolah mampu menghasilkan siswa berkualitas. 3) Kepada Peneliti Lain. Berdasarkan temuan penelitian, disarankan kepada peneliti agar hasil penelitian ini digunakan sebagai referensi untuk melaksanakan penelitian selanjutnya atau menemukan inovasi kegiatan pembelajaran lainnya yang bermakna bagi siswa. 


\section{Daftar Rujukan}

Agung, Anak Agung Gede. 2014. Metodologi Penelitian Pendidikan.Singaraja :Undiksha.

Al-Tabany,Trianto Ibnu Badar.2015. Mendesain Model Pembelajaran Inovatif, Progresif, Dan Kontekstual. Jakarta : Prenadamedia Group.

Fatimah, Soewarno, Suci. 2016. Pengaruh Model Pembelajaran Picture And Picture Terhadap Hasil Belajar Pada Subtema Indonesiaku, Bangsa Yang Berbudaya Kelas V Banda Aceh. Jurnal Ilmiah Pendidikan Guru Sekolah Dasar FKIP Unsyiah Volume 1 Nomor 2,19-25.

Fauziah, Tati, Yoserizal Bermawi. 2014. Penerapan model kooperatif tipe picture And picture Pada materi peninggalan sejarah Disekolah dasar Negeri banda aceh. Pendidikan Guru Sekolah Dasar(PGSD) JURNAL PESONA DASAR Universitas Syiah Kuala Vol. 2 No.3, hal79-87

Handayani, Ni Made Dwi, Ni Nyoman Ganing, Ni Wayan Suniasih. 2017. Model Pembelajaran Picture And Picture Berbantuan Media Audio-Visual Terhadap Kompetensi Pengetahuan Ipa . Journal of Education Technology. Vol. 1 No. (3) pp. 176-182

Huda, Miftahul.2013. Model-model Pembelajaran dan Pembelajaran. Yogyakarta : Pustaka Pelajar.

Husein, Latifah. 2017. Profesi Keguruan Menjadi Guru Profesional. Yogyakarta: Pustaka Baru Press.

Istanti, Andriana Wahyu, H. A. Triwidjaja. 2014. Penerapan Model Pembelajaran Picture And Picture Pada Pembelajaran Ipa Anak Tunagrahita SDLB. JURNAL P3LB, VOLUME 1, NOMOR 2, PP 169-174.

Jaya, I Kd. Putra, I Kt. Adnyana Putra, I Wyn. Darsana. 2014. Model Pembelajaran Picture And Picture Berpengaruh Berbantuan Kemampuan Berpikir Kreatif Siswa Dalam Pembelajaran Ipa Kelas V Sd Gugus Budi Utomo. e-Jurnal Mimbar PGSD Universitas Pendidikan Ganesha Jurusan PGSD Vol. 2 No. 1

Kadir,dkk. 2012. Dasar-dasar Pendidikan. Jakarta:Kencana Prenadamedia Group.

Kurniati, Ni Md., Dw. Nym. Sudana, Ni Nym. Garminah. 2014. Pengaruh Metode Picture And Picture Terhadap Hasil Belajar Ipa Siswa Kelas Iv Sd Semester Genap Di Gugus I Kecamatan Buleleng. EJournal Universitas Pendidikan Ganesha Volume 2 No 1.

Purwanto. 2011. Evaluasi Hasil Belajar. Yogyakarta : Pustaka Belajar.

Rusman.2016.Modelmodel..Pembelajaran:Mengembangkan Profesionalisme Guru. Jakarta: Rajawali Pres.

Sanjaya, Wina. 2009. Kurikulum Dan Pembelajaran : Teori dan Praktik Pengembangan Kurikulum Tingkat Satuan Pendidikan (KTSP). Jakarta: Prenada Media Group.

Setyosari,Punaji..2015..Metode..Penelitian Pendidikan\& Pengembangan. Jakarta:Prenadamedia Group.

Sugiyono.2012. Metode Penelitian Pendidikan.Bandung: Alfabeta.

Susanti, Putu Ari, Ni Nyoman Kusmariyani. 2017. Penerapan Model Picture And Picture Berbasis Pendekatan Saintifik Untuk Meningkatkan Hasil Pengetahuan IPA. Jurnal Ilmiah Sekolah Dasar Universitas Pendidikan Ganesha Volume 1 Nomor 2 hal 99-106.

Wisesa, I.G.A Riani, Md. Putra,DB Kt. Ngr. Semara Putra. 2014. Strategi Peer Lessons Berbantuan Picture And Picture Berpengaruh Terhadaphasil Belajar Ips Siswa Kelas V. Jurnal Mimbar PGSD Universitas Pendidikan Ganesha Jurusan PGSD Vol: 2 No: 1

Wisudawati, Asih Widi. Sulistyowati,Eka.2015. Metodologi Pembelajaran IPA. Jakarta: Bumi Aksara.. 